Драгомир В. Козомара

Универзитет у Бањој Луци

Филолошки факултет

Студијски програм српског

језика и књижевности

https://doi.org/10.18485/ai_fonefonosj.2020.ch8

811.163.41'271.16(497.5 Бањалука)

\title{
ИЗГОВОРНЕ ВРИЈЕДНОСТИ КОНТИНУАНАТА ДУГОГ ВОКАЛА ЈАТ У ГОВОРУ МЛАДИХ БАЬАЛУКЕ**
}

Одавно је запажено да ијекавски рефлекси некадашњег вокала jam који је по поријеклу био дуг, у говорној пракси веома често одступају од важеће српске ортоепске норме. С тим у вези, овај рад представља покушај да се утврди у ком правцу иде развој говора бањалучке омладине.

На узорку од 50 испитаника - ученика средњих школа и студената који су све вријеме од рођења живјели у Бањалуци - анализиране су изговорне вриједности некадашњег дугог вокала jam у говору ове популације становништва. Испитаници су на ијекавској варијанти изговарали дванаест ријечи у којима се јављају различите позиционе варијанте дугих екавских континуаната јата. Резултати завршене анализе не иду у прилог нашој акценатској норми - чињенично стање је такво да су у говору младих Бањалуке стандардни рефлекси готово занемариви.

Кључне ријечи: вокал јат, рефлекси дугог јата, говор младих Бањалуке.

\section{* dragomir.kozomara@flf.unibl.org}

* Овај рад (са радном верзијом „Изговорне вриједности некадашњег вокала jam у говору младих Бањалуке") саопштен је на научном скупу Актуелна питаға фонетике и фонологије српског језика, одржаном у Андрићевом институту у Андрићграду 5. октобра 2019. године. 


\section{I. Уводне напомене}

По угледу на Вукову и Даничићеву акцентуацију, у скоро свим граматикама, рјечницима и различитим приручницима српског језика (и старијег и новијег датума) нормирано је да се према некадашњем старом дугом вокалу јат са узлазном интонацијом, у ијекавској књижевној варијанти изговара ијѐ (дијѐте, вријѐме и сл.), а да се према дугом јату са дугосилазном интонацијом говори йје (бйјел, цийјелй и др.).

О рефлексима некадашњег вокала jam у нашој литератури написан је велики број научних студија, од оних ситнијих па до читавих монографија. Да је принцип по ком један кратки слог има вриједност једне море, а дуги двије море (Симић-Остојић 1989: 218) у српским ијекавским говорима одавно нарушен (или никада није ни постојао?!) кад су у питању изговорне вриједности дугог јата, већ је указано у низу до сад објављених радова у којима је обрађивана јатовска проблематика ијекавске говорне варијанте. Ипак, без обзира на ову неспорно утврђену чињеницу, корекција норме остала је на констатовању фактичког стања и позивању на усклађивање са стандардом или је, евентуално, сведена на „стидљиве” препоруке да би понешто требало и мијењати.

Овај рад настао је са циљем да се на основу континуаната дугог јата утврди у ком правцу иде говор младих Бањалуке, највећег града Републике Српскепо броју становника, њеног водећег културног и економског центра и данас бројчано најмногољуднијег мјеста на територији коју обухватају млађи штокавски ијекавски говори као компактна цјелина. Исто тако, циљ је био и да се, на основу поређења са стандардним језиком, утврди колико је наша актуелна прозодијска норма компатибилна са стањем у живом говору младих Бањалучана. (Истраживање је усмјерено искључиво на изговорне вриједности вокала јат 
у дугим слоговима, јер су рефлекси кратког јата у готово свим позицијама подударни са стандардним.)

Бањалучки ђаци и студенти од којих је добијена овдје презентована грађа већином су потомци аутохтоних Бањалучана или досељеничког становништва које се настанило у Бањалуку у периоду грађанског рата у Босни и Херцеговини од 1992. до 1995. године. Иако говор бањалучке омладине тек треба да се детаљније опише, већ се доста поуздано може устврдити да је то прилично хомогена језичка структура са тенденцијом даљег уједначавања. Наравно, утицај говора младих Бањалучана, престижног у овом ареалу, осјети се и у говору млађе популације мимо бањалучке регије.

Истраживање српских урбаних говора, као што је познато, још се налази у почетној фази. Говор младих Дервенте (Цукут 2013) представља засад једину студију о градском говору на простору који заузима источнохерцеговачки дијалекат, те се компаративна анализа података добијених у овом истраживању морала углавном свести на порећење са постојећим описима руралних говора.

\section{II. Гpaђ $a^{1}$}

За истраживање континуаната дугог јата у говору младих Бањалуке грађа је добијена од 50 испитаника. Циљано су бирани ученици бањалучких средњих

1 Као што је то обично у радовима овакве врсте, а поготову кад су у питању ијекавски рефлекси некадашњег дугог вокала jam, и овдје морамо напоменути да се грађа која ће бити презентована не може узимати безрезервно, јер аудитивна перцепција у оваквим истраживањима увијек има ограничене домете, па су и евентуалне омашке сасвим очекиване. Мимо тога, додатне компликације стварају и различите говорне ситуације, првенствено бржи темпо говора. Ипак, надамо се да највећи дио ексцерпираних података даје вјерну слику континуаната дугог јата у говору младих Бањалучана. 
школа и студенти Универзитета у Бањалуци којима је овај град био једино мјесто пребивалишта од њиховог рођења. С обзиром на то да је на рефлексе дугог јата у ранијој литератури указано као на једну од изоглоса које дијеле сјеверозападну скупину говора источнохерцеговачког дијалекта (в. Драгичевић 1986: 226-228, Ивић 1996: 146 и Драгичевић 2001: 86-87), од испитаника су, због очекиваног утицаја на њихов говор, узети и подаци о мјесту одакле им потичу родитељи.

Током истраживања испитаници су на ијекавској варијанти изговарали дванаест ријечи написаних екавском варијантом. (Из разумљивог разлога, списак ријечи чинили су екавски облици да би их испитаници, без графијског утицаја ијекавских континуаната јата, што вјерније представили у ијекавским формама.) Одабир ријечи је такав да се у њима огледају различите позиционе варијанте континуаната јата. Тако су узете двије ријечи гдје се узлазни акценти налазе на првом слогу (време, дете), те двије ријечи у којима су узлазни акценти на унутрашњим слоговима (оценити, приметити). Четири су ријечи са акцентима силазне интонације, од којих су двије једносложне (вест, иев), а двије двосложне (вести, цеви). На списку су и двије ријечи у којима се јављају дуги рефлекси јата настали секундарним дужењем (намештати, верник), као и двије ријечи у којима се континуанти јата налазе у постакценатској позицији (оценим, опредељен).

При избору ријечи, како се види, водило се рачуна и о гласовном окружењу у ком су се налазили рефлекси вокала јат.

Након спроведеног истраживања добијени су сљедећи резултати:

Према некадашњем jamy са дугоузлазном интонацијом, код свих испитаника редовно се јавља дуго- 
узлазни акценат на вокалу е. Компонента $u$ из првог дијела некадашњег дифтонга (уколико није потпуно елиминисана, што је забиљежено у два случаја: дjéme и оије́нити) редовно је неслоговна и дјелимично редукована, те се изговор остварује у гласовним реализацијама вр јее́ме, дије́те, ойје́нити, примије́тити. Нисмо нашли ниједну потврду стандардног изговора са краткоузлазним акцентом на вокалу е типа вријѐме, дијѐте и сл.

И код континуаната јата са дугосилазним акцентом скоро редовно долази неслоговно и дјелимично редуковано $u$, а на вокалу е остварује се дугосилазни акценат:

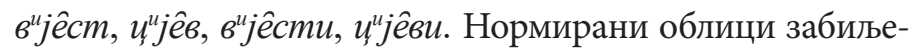
жени су код три испитаника, и то на једносложним ријечима вйјест (у једном случају) и цүйјев (два пута).

Дакле, на основу изложене грађе може се резимирати да су резултати гласовног декомпоновања некадашњег дугог акцентованог вокала јam у готово свим случајевима у суштини исти, а разлика је само у акценту, који се, како је речено, остварује са дугоузлазном интонацијом на компоненти е према стандардном краткоузлазном $e$, а са дугосилазном интонацијом према стандардном краткосилазном $\mathcal{u}$.

Као и већина оних рефлекса у којима је јат био примарно дуг, идентично се понашају и рефлекси секундарно продуженог јата, па је мање-више редовно: намије́штати, вијернйк. Приликом изговарања наведена два облика, компонента $u$ из сваког од њих по два пута потпуно је редукована, а акценат је остао непромијењен: намје́штати, вјеิрнйк.

Неслоговност и дјелимична редукција вокала $u$ општа су одлика и континуаната дугог јата у ванакценатској позицији, а други дио секвенце, вокал $e$ - редов- 
но се јавља са постакценатском дужином, те је у већини случајева: о̀йјенйм, опрѐдјёьен. Три пута забиљежено је опрѐдјёьен.

Мимо поменутих примјера у којима се спроводе потпуне редукције компоненте $u$, за све остале рефлексе карактеристично је да су секвенце некадашњег дифтонга раздвојене прелазним $j^{2}$.

У суштини, ако занемаримо прилично ријетка одступања, можемо констатовати да су континуанти дугог вокала jam у говору младих Бањалуке сведени на сљедеће стање: врије́ме : вије̂сm : намије́штати : вијерр-

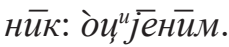

\section{III. Дискусија}

Без претензије да се улази у детаљније теоретско разматрање о вокалу jam, најсложенијем питању у историји српског језика (Белић 1999: 80), овдје ћемо се осврнути на раније описе западнијих српских говора који се могу довести у блиску везу са нашим истраживањем, а првенствено на оне у којима су неки од истражених пунктова управо на подручју које административно припада бањалучкој општини.

У три кључна рада о српским западнобосанским ијекавским говорима - монографијама Д. Петровића (Петровић 1973), М. Дешића (Дешић 1976) и С. Далмације

2 „Јача асимилаторна снага другог, отворенијег елемента старог дифтонга његов високо затворени први дио свелаје на редукован вокалски елеменат боје $u$, који је изгубио слоготворност, што је истовремено, дисимилационим процесом, условило да се прелазно $j$ изразитије реализује, да ојача у фонетском смислу" (Рамић 1999: 421). 
(Далмација 1997) $^{3}$, генерално гледано, готово редовно налазимо нестандардне изговорне варијанте рефлекса некадашњег дугог јата са дугоузлазним акцентом, а прилично сличне кодификованим оне рефлексе у којима је јат био под дугосилазним акцентом ${ }^{4}$.

Наводећи много већи број рефлекса у којима је дуги јат дао ије́ од оних класичних ијѐ, Д. Петровић за змијањски говор каже: „Уосталом, овде је једино важно питање да ли је ѐ у секвенци ијѐ, дуже од ѐ у осталим позицијама у истом говору. За мене оно јесте дуже" (Петровић 1973: 218), те додаје да континуант ӥје у овом говору „не показује битнијих одступања од одговарајућег стања у књижевном језику", као ни рефлекс дугог јата у постакценатској позицији (Исто: 219-220).

Слично је и у грађи М. Дешића (1976) и С. Далмације (1997): обично се јављају континуанти ије́, йје, с тим да су у крајишким говорима прилично честе редукције компоненте $u$ па се срећу и облици са је́ и је̂ (в. Дешић 1976: 99-109 и Далмација 1997: 26-29). Ни Дешић ни Далмација немају наведен ниједан стандард-

3 Ово су и једине монографије о српским западнобосанским ијекавским говорима западније од ријеке Врбас. У свакој од њих налази се по неколико пунктова са подручја Бањалуке.

4 За говоре југоисточне скупине источнохерцеговачког дијалекта много раније утврђено је да се изговорне вриједности дугог јата који је имао дугоузлазни акценат не подударају са нормираним рефлексом ије. Тако, нпр., Г. Ружичић у пљеваљском говору налази рефлекс ије́ (Ружичић 1927: 113), а исти такав рефлекс биљежио је и А. Пецо у источнохерцеговачком говору, гдје је вокал е сачувао „дио своје дужине и послије цијепања дифтонга у два слога" (Пецо 1964: 50). J. Вуковић у говору Пиве и Дробњака налази да „узлазни акценат гласа $e$ из групе uje, од гласа jam, стоји квантитетски између обичног кратког узлазног и дугог узлазног" (Вуковић 1938-39: 14). У свим овим говорима стандардне вриједности јављају се код акцената силазне интонације. 
ни облик са ијѐ, а Дешић притом напомиње: „уо сам га свега неколико пута, али то је било у брзом темпу говора, кад се скраћују сви дуги акценти, тако да се овај податак не може узимати као доказ о постојању класичног рефлекса ије”" (Дешић 1976: 110). Код Дешића налазимо и податке да се у ванакценатској позицији често могу појавити рефлекси $u(j \bar{e})$ (Исто: 106-109).

Новије студије о српским западнобосанским говорима источнохерцеговачког дијалекта, као и о говорима нешто источније од ријеке Врбас готово без изузетка су потврдиле оно што су за судбину рефлекса ије насталог од јата са дугоузлазним акцентом констатовали Петровић, Дешић и Далмација: да је краткоузлазни акценат на компоненти $е$ готово непознат у овим говорима, али и доказале да се веома интензивно одвија још један процес - уједначавање рефлекса̄ дугог јата на стање $\dot{\hbar}$ $>$ ujé; $\hat{b}>{ }^{u} \hat{e} ; \bar{\hbar}>{ }^{u} j \bar{e}$, што је, како је показала презентована грађа, случај и у говору младих Бањалуке. Тако су континуанти дугог јата које смо забиљежили код бањалучке омладине мање-више подударни са онима који су навођени у радовима о: говору Срба доњег Ливањског поља (Рамић 1999: 423-424), говору Чечаве (Козомара 2005: 25-26), говору младих Дервенте (Цукут 2013: 19-20), говору Јаворана (Црњак-Козомара 2015: 703), српским посавским говорима између Врбаса и Укрине (Козомара 2016: 628-629). Има их, мада нису тако досљедни, и у Бранешцима (Драгичевић 2003: 306-307), Кремни (Драгичевић 2007: 336-337, Бањи Врућици (Драгичевић 2007: 104-105), у околини Шипова (Цукут 2018: 37-40) и др. Укупан број примјера наводи и на закључак да је свођење на овакве рефлексе jата управо у говору младих Бањалучана најпрогресивније узнапредовало и скоро достигло завршну фазу, 
те за њихов говор више не важи Вуковићева тврдња по којој „кад је једанпут добијено у већини ијекавских говора двосложно ије место јата под силазним акцентом, са акцентом на првом вокалу двосложне замене, нема услова да се тај изговор помера у корист једносложног јекавског изговора, баш зато што је $u$ под акцентом" (Вуковић 1951: 34). Овдје се акценат помјерио на други дио компоненте некадашњег дифтонга, на вокал $e$, јер на $u$ више не лежи интонационо и димамичко тежиште.

\section{IV. Закључна разматрања}

Уравнавање континуаната дугог вокала јат у говору младих Бањалуке на однос вр је́ме : в је̂ст : намије́штати : вијернйк: о̀ијјенйм још једном отвара веома важно питање: Да ли је дошло вријеме за измјену постојеће ортоепске норме српског језика? Очигледно је да јесте, а ево и неких аргумената.

Ма колико да су нормативисти истрајавали на очувању традиционалне Вукове и Даничићеве акцентуације, језичке појаве у живом говору ишле су својим током и овакви ијекавски рефлекси дугог јата резултат су језичке еволуције и незаустављивог процеса који, чини се, улази у своју завршну фазу. На основу оног што је већ предочено у неколико овдје поменутих радова и додатно употпуњено нашим истраживањем, сасвим је јасно да имамо ортоепску норму која је, у суштини, потпуно инкомпатибилна са стањем у живом говору.

Говор Бањалуке (из горе већ наведених разлога) данас се мора узимати као мјерило и као полазна основа за ијекавски стандард, а да би се добила комплетна слика говорног стања, потребно је урадити додатна слична истраживања и у другим значајнијим градским центрима у којима живе новоштокавци ијекавци. 
Све овдје наведено даје нам за право да констатујемо да ортоепску норму српског језика, за почетак, треба барем кориговати увођењем акценатских дублета типа: дијете/дије́те; вйјек/вијекк; ӱвијек/уввијек, чиме би се кодификовано стање приближило изговорном, при чему дистрибуциона правила наших акцената (поштујући стари принцип да се рефлекс ије настао од некадашњег јата узима као један слог) не би била нарушена.

\section{ЛИТЕРАТУРА}

Белић 1999: А. Белић, Историја српског језика (Фонетика, Речи са деклинацијом, Речи са конјугацијом), Изабрана дела Александра Белића, Београд: Завод за уџбенике и наставна средства.

Вуковић 1938-39: J. Вуковић, Говор Пиве и Дробњака, ЈФ, XVII, 1-113.

Вуковић 1951: J. Vuković, Ije - je ili samo je u jugozapadnom književnom narečju, Pitanja savremenog književnog jezika, II, sv. 1, 33-39.

Далмација 1997: С. Далмација, Ијекавски говори Поткозарја, Бањалука, 1-264.

Дешић 1976: М. Дешић, Западнобосански ијекавски говори, Српски дијалектолошки зборник, XXI, Београд, 1-316 + карте.

Драгичевић 1986: М. Драгичевић, Говор личких јекаваца, Српски дијалектолошки зборник, XXXII, Београд, 7-238 + карте.

Драгичевић 2001: М. Драгичевић, Најзападнији српски говори данас, у: М. Драгичевић (ур.), Зборник за српски језик, књижевност и умјетности, књига I, Бања Лука, 79-89.

Драгичевић 2003: М. Драгичевић, О говору села Бранешци у околини Челинца, Српски језик, VIII/1-2, Београд, 303314.

Драгичевић 2007: М. Драгичевић, О говору Срба Бање 
Врућице крај Теслића I (фонетске и морфолошке особине), Сриски дијалектолошки зборник, LIV, Београд, 323-401.

Драгичевић 2008: М. Драгичевић, Белешке о говору села

Кремне у западној Босни, Српски језик, 13/1-2, Београд, 103-111.

Ивић 1956: П. Ивић, Дијалектологија српскохрватског језика (Увод и штокавско наречје), Нови Сад: Матица српска.

Ивић 1996: П. Ивић, О језику, Група аутора, Република Српска Крајина, Книн-Београд, 143-158.

Козомара 2005: Д. Козомара, Говор Чечаве (села у сјевероисточном дијелу опитине Теслић), Филозофски факултет у Бањалуци, магистарски рад у рукопису, 141 стр.

Козомара 2016: Д. Козомара, Фонетске и морфолошке особине српских посавских говора између Врбаса и Укрине, Српски дијалектолошки зборник, LXIII, Београд, 583733.

Петровић 1973: Д. Петровић, О говору Змијаюа, Библиотека ЗФЛ XIV/1-2 и XV/1-2, Нови Сад.

Пецо 1964: А. Пецо, Говор источне Херцеговине, Српски дијалектолошки зборник, XIV, Београд, 1-200 + карта.

Рамић 1999: Н. Рамић, Стање континуаната јата у говору Срба доњег Ливањског поља, Српски језик, IV/1-2, Београд, 419-446.

Ружичић 1927: Г. Ружичић, Акценатски систем пљеваљског говора, Српски дијалектолошки зборник, III, Београд, 113-176.

Симић-Остојић 1989: Р. Симић - Б. Остојић, Основи фонологије српскохрватскога книжевног језика, Никшић.

Црњак-Козомара 2015: Д. Црњак - Д. Козомара, О вокализму говора Јаворана, Сриски језик, XX, Београд, 697-710. Цукут 2013: С. Цукут, Говор младих Дервенте, Филолошки факултет у Бањој Луци, магистарски рад у рукопису, 105 стр.

Цукут 2018: С. Цукут, Српски говори околине Шипова, докторска дисертација у рукопису, Филолошки факултет у Бањој Луци, 198 стр. 
Dragomir V. Kozomara

\section{THE PRONUNCIATIONAL VALUES OF CONTINUANTS OF THE LONG VOWEL YAT IN THE SPEECH OF THE YOUTH FROM BANJA LUKA}

\section{Summary}

The paper analyses the pronunciational values of the former long vowel yat in the speech of the youth from Banja Luka, based on the sample of fifty questionees, all of which are the secondary school and university students who have been living in Banja Luka from their birth up to the present.

During the research, the questionees have pronounced, using the Ijekavian variant, twelve words spelled in the Ekavian variant, chosen in such a way that they should reflect different positional variants ofthe yat continuant: vreme, dete; oceniti, primetiti; vest, cev; vesti; cevi; nameštati, vernik; ocenim, opredeljen;

The following are the research results:

In accordance with the Ekavian long $e$ with the long-rising intonation, withallquestioneesthereisaregularoccurrenceofthelongrising accent on the vowel $e$ : vrijéme, dijéte, oc jéniti, primijétiti. In a smaller amount of cases, the $i$ component has totally been reduced (djéte, ocjéniti). In accordance with the Ekavian long $e$ with the long-falling accent, there is a realisation of the long-falling accent: $v^{i} j e ̂ s t, c^{i} j e ̂ v, v^{i} j e ̂ s t i, c^{i} j e ̂ v i$. Standardised forms have been noted with three questionees only, those being on monosyllabic words vïjest and cïjev.

The reflexes of the secondarily lengthened yat behave in a manner which is equally the same as with those with which the yat is primarily long, therefore we have: namijéstati, $v^{i} j e ̂ r n i k$.

The $i$ component has also been reduced (partially, almost always, yet rarely fully) in the non-accentual position, and the $e$ is kept long: òc $i \overline{j e n i m}$, oprè $d^{i} \overline{j e} l j e n$.

Key words: the vowel yat, reflexws of the long vowel yat, the speech of the youth from Banja Luka. 